\title{
The prevalence of IgE-dependent food allergy in asthmatic children
}

\author{
A Krogulska*, J Białek, M Funkowicz, K Wąsowska-Królikowska \\ From Food Allergy and Anaphylaxis Meeting (FAAM 2013) \\ Nice, France. 7-9 February 2013
}

\section{Background}

Food allergy is rarely considered a trigger for asthma. However, the each part of respiratory tract may be an effector organ of allergic reaction provoked by food. The aim of this study was to evaluate the prevalence of IgEdependent food allergy in asthmatic children.

\section{Methods}

The initial study group consisted of 506 children with atopic asthma, aged 6-18 years. Methodology included: history, physical examination, pulmonary function tests, skin prick tests (SPT), specific IgE using the UniCAP 100 Pharmacia Upjohn and oral challenge tests, which were performed using the DBPCFC method.

\section{Results}

Based on a survey showed that 180/362 (49.7\%) children with asthma had symptoms that were associated with the consumption of food. Sensitization to food allergens was found in $70(19.3 \%)$ children with asthma. Oral provocation tests using DBPCFC was performed in 50 children with asthma, in whom the results of the interview and / or SPT and / or specific IgE indicated a possible involvement of food allergens on symptoms of IgEmediated reactions. The positive results of oral food tests was found in 20 (5.5\%) children with asthma. After including 4 children with a well-documented history of anaphylactic reactions, IgE-mediated food allergy was diagnosed in 24 patients with asthma (6.6\%). Respiratory symptoms as a result of oral food challenges occurred in $3 \%$ of children with asthma, however the asthmatic symptoms related to $9 / 362(2.5 \%)$ of the children.

Department of Pediatric Allergology, Gastroenterology and Nutrition, Medical University Łódź, Łódź, Poland

\section{Conclusion}

IgE-dependent food allergy was diagnosed in $6.6 \%$ of children with asthma. Respiratory symptoms as a result of food allergen provocation occurred in 3\% of children with asthma.

\section{Disclosure of interest}

None declared.

Published: 25 July 2013

\section{References}

1. James JM, Bernhisel-Broadbent J, Sampson HA: Respiratory reactions provoked by double-blind food challenges in children. Am J Respir Crit Care Med 1994, 149:59-64.

2. Bousquet J, Chanez P, Michel F: Problemy szczegółowe: alergia pokarmowa w przebiegu astmy w Astma oskrzelowa..

3. O'Byrne PM, Thomson NC: $\alpha$-medica Press; 1995, 811-821.

4. Penard-Morand C, Raherison C, Kopferschmitt C, Caillaud D, Lavaud F, Charbin D, et al: Prevalence of food allergy and its relationship to asthma and allergic rhinitis in schoolchildren. Allergy 2005, 60:1165-1171.

doi:10.1186/2045-7022-3-S3-P61

Cite this article as: Krogulska et al:: The prevalence of IgE-dependent food allergy in asthmatic children. Clinical and Translational Allergy 20133

Submit your next manuscript to BioMed Central and take full advantage of:

- Convenient online submission

- Thorough peer review

- No space constraints or color figure charges

- Immediate publication on acceptance

- Inclusion in PubMed, CAS, Scopus and Google Scholar

- Research which is freely available for redistribution (Suppl 3):P61. 